
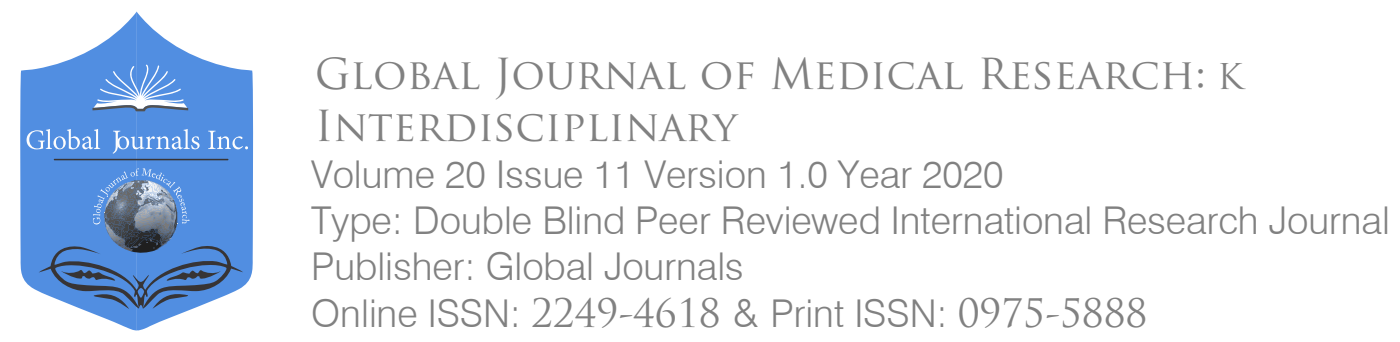

\title{
Research on the Combination of Commercially Available Thickeners and Commercially Available Nursing Food -Aiming for Viscosity Adjustment that can be done at Home
}

By Mayumi Hirabayashi, Shoko Kondo \& Naomi Katayama

Nagoya Women's University

Abstract- Japan is a supper-aged society, and many older adults need home care. To provide meals safely at home, the viscosity of meals suitable for the elderly required. Therefore, in this study, the viscosity was measured by combining two types of thickeners that can purchase at pharmacies and three types of care foods. The thickener used this time has almost the same price and content, but the many included material is different. Thickener A was rich in watersoluble dietary fiber, and thickener B was rich in thickening polysaccharides. The three types of foods were foods with high carbohydrate content, high lipid content, and high water content. As a result, thickening agent $B$, which is rich in thickening polysaccharides, was able to maintain the viscosity better than thickening agent $A$ if a thickening agent added at a low $(100 \mathrm{~g}$ food per $1 \mathrm{~g}$ thickening) concentration to foods rich in lipids and water. However, when the addition amount of the thickener was large, the thickener A and the thickener B showed almost the same viscosity. It will be necessary to increase the number of samples and clarify the differences due to the combinations.

Keywords: thickener, nursing food, viscosity test.

GJMR-K Classification: NLMC Code: WA 695

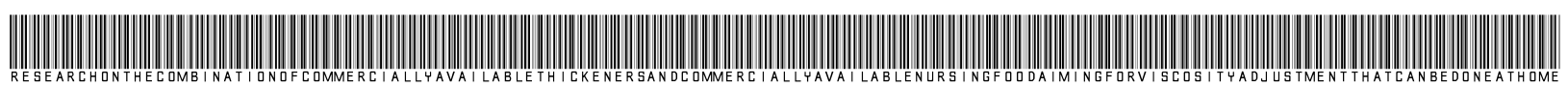

Strictly as per the compliance and regulations of:

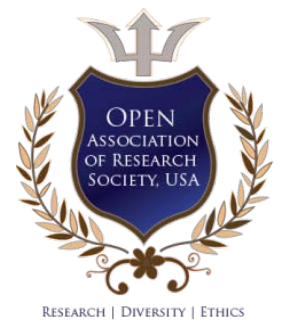

(c) 2020. Mayumi Hirabayashi, Shoko Kondo \& Naomi Katayama. This is a research/review paper, distributed under the terms of the Creative Commons Attribution-Noncommercial 3.0 Unported License http://creativecommons.org/licenses/by-nc/3.0/), permitting all non-commercial use, distribution, and reproduction in any medium, provided the original work is properly cited. 


\title{
Research on the Combination of Commercially Available Thickeners and Commercially Available Nursing Food -Aiming for Viscosity Adjustment that can be done at Home
}

\author{
Mayumi Hirabayashi ${ }^{\alpha}$, Shoko Kondo ${ }^{\sigma} \&$ Naomi Katayama ${ }^{\rho}$
}

\begin{abstract}
Japan is a supper-aged society, and many older adults need home care. To provide meals safely at home, the viscosity of meals suitable for the elderly required. Therefore, in this study, the viscosity was measured by combining two types of thickeners that can purchase at pharmacies and three types of care foods. The thickener used this time has almost the same price and content, but the many included material is different. Thickener A was rich in water-soluble dietary fiber, and thickener $B$ was rich in thickening polysaccharides. The three types of foods were foods with high carbohydrate content, high lipid content, and high water content. As a result, thickening agent $B$, which is rich in thickening polysaccharides, was able to maintain the viscosity better than thickening agent $A$ if a thickening agent added at a low (100g food per $1 \mathrm{~g}$ thickening) concentration to foods rich in lipids and water. However, when the addition amount of the thickener was large, the thickener $A$ and the thickener $B$ showed almost the same viscosity. It will be necessary to increase the number of samples and clarify the differences due to the combinations.
\end{abstract}

Keywords: thickener, nursing food, viscosity test.

\section{INTRODUCTION}

T he scene of care in Japan is very severe. Japan has been aging faster than the other Asian countries since the 1970s. Due to changes in the industrial structure, the people's living environment and family structure have changed rapidly. The Japanese government worked to secure and develop human resources who are engaged in long-term care, as well as promoting various policies and systems aimed at establishing a system for providing public long-term care services. Since the establishment of the long-term care insurance system in 2000, Japanese elderly care services have expanded dramatically in both quality and quantity. However, there is no facility that can accommodate all the elderly peoples who are increasing in the future. Alao, since a large amount of money is

Author $\alpha$ : Graduate School of Nagoya Women's University, Nagoya City, Japan

Author $\sigma$ : Watanabe Hospital, Noma, Aichi, Japan

Corresponding Author o: Naomi Katayama, Nagoya Women's University, Nagoya City, 4678610, Japan. And Graduate School of Nagoya Women's University, Nagoya City, Japan.

e-mail: naomik@nagoya-wu.ac.jp required to move into the facility, we must consider home care in the future. It is important to have meals at the nursing care site three or more times daily, and it is necessary to provide safe and tasty meals. When considering the swallowing function, the viscosity of the meal in providing a safe diet is one of the necessary items. We focused on the viscosity in the diet. We thought that nursing care at home would be safer if ordinary households coulds imply provide the viscosity of the meal to the target person. Suppose we can measure the viscosity of the meal and then use a thickener to create a viscosity that suits the person eating the meal. We feel that home care is safe. Therefore, the purpose of this study was to create usable data for nursing food guidance that can create when a registered dietitian visits at home and in the nursing class.

\section{il. Material and Methods}

\section{a) Commercially Available Thickeners}

Two types of products sold at pharmacies used as commercially available thickeners. Thickener A was 1296 yen (12 USD), including 50 packs of 3 grams. The raw materials are dextrin, water-soluble dietary fiber, and xanthan gum. The nutritional content per 3 grams is that $8.1 \mathrm{kcal}$ energy, $0 \mathrm{~g}$ protein, $0 \mathrm{~g}$ lipid, $2.04 \mathrm{~g}$ sugar, $0.75 \mathrm{~g}$ dietary fiber, and $18.6 \mathrm{mg}$ sodium. Thickener B was 1274 yen (11.54 USD), including 50 packs of 3 grams. The raw materials are dextrin, thickening polysaccharides, potassium chloride, and sucralose. The nutritional content per 3 grams is that $7.9 \mathrm{kcal}$ energy, $0 \mathrm{~g}$ protein, $0 \mathrm{~g}$ lipid, $1.9 \mathrm{~g}$ sugar, $0.7 \mathrm{~g}$ dietary fiber, and $16 \mathrm{mg}$ sodium.

\section{b) Commercially Available Nursing food}

Three types of products used from the easy-tochew category of the universal design food (UDF) on the market. These are Demiglace sauce hamburger, Boiled Fried Tofu as Kyoto style, and White meet fish dumpling with Egg Sauce. All of them are $100 \mathrm{~g}$ retort pouches and sold for 180 yen (1.67 USD). The nutritional value of Demiglace sauce hamburger was $89 \mathrm{kcal}, 4.3 \mathrm{~g}$ protein, $4.0 \mathrm{~g}$ lipid, $8.9 \mathrm{~g}$ carbohydrates, and $0.81 \mathrm{~g}$ salt equivalent per 100 grams. The nutritional value of Boiled Fried Tofu 
as Kyoto style was $91 \mathrm{kcal}, 5.1 \mathrm{~g}$ protein, $6.0 \mathrm{~g}$ lipid, $4.1 \mathrm{~g}$ carbohydrates, and $0.81 \mathrm{~g}$ salt equivalent per 100 grams. The nutritional value of White meet fish dumpling with Egg Sauce was $62 \mathrm{kcal}, 3.6 \mathrm{~g}$ protein, $3.0 \mathrm{~g}$ lipid, $5.2 \mathrm{~g}$ carbohydrates and $0.92 \mathrm{~g}$ salt equivalent per 100 grams.

\section{c) Sample (food with a thickener added) adjustment}

Each of the three foods prepared as five samples. First, the viscosity of the food product itself measured without any modification. Secondly, the food was pulverized for 20 seconds using a mixer into a liquid state, and the viscosity measured. Third, the viscosity was measured after adding 1 gram of thickener (A or B) to the food $(100 \mathrm{~g})$ ground for 20 seconds with a mixer and stirring for 5 minutes. Fourth, the viscosity measured after adding 2 grams of thickener ( $\mathrm{A}$ or $\mathrm{B}$ ) to the food (100g) ground for 20 seconds with a mixer and stirring for 5 minutes. Fifth, the viscosity measured after adding 3 grams of thickener ( $\mathrm{A}$ or $\mathrm{B}$ ) to the food $(100 \mathrm{~g}$ ) ground for 20 seconds with a mixer and stirring for 5 minutes.

\section{d) Viscosity measurement method}

The viscosity of each fod was measured using the Line Spread Test Start Kit (LST) manufactured by SARAYA. The measurement procedure is as follows. The viscosity test performed at room temperature (24 degrees). The test repeated three times and the average value calculated.

1. Place the sheet on a level surface. Place a ring with an inner diameter of $30 \mathrm{~mm}$ in the center of the concentric circles.

2. Add the liquid to be measured to the full thickness of thering $(20 \mathrm{ml})$ and let stand for 30 seconds.

3. Lift the ring vertically, and after 30 seconds, measure the spread distance of the solution. Since there are a total of 6 points to measure, the average value of them used as the LST value.

4. After still standing for 5 minutes, the spread of the samples is measured again at 6 points, and the average value recorded as the LST value.

\section{e) Criteria for viscosity}

There are three levels of classification by LST value1). The first stage is the mildly thick with a viscosity that falls within the rage of $43 \mathrm{~mm}$ to $36 \mathrm{~mm}$ (50-150
$\mathrm{mPa} \cdot \mathrm{s})$. As for the properties, when the spoon is tilted, it flows down quickly ${ }^{11}$. The second stage is moderately thick with a viscosity that falls within the range of $36 \mathrm{~mm}$ to $32 \mathrm{~mm}(150-300 \mathrm{mPa} \cdot \mathrm{s})$. As for the properties, when you tilt the spoon, it flows to the surface ${ }^{1)}$. The third stage is extremely thick with a viscosity that falls within the range of $32 \mathrm{~mm}$ to $30 \mathrm{~mm}(300-500 \mathrm{mPa} \cdot \mathrm{s})$. Even if the spoon is tilted, the shape maintained to some extent and it does not flow easily ${ }^{11}$.

\section{f) Statistical processing}

This study was statistically processed using statistical processing software, Excel 2010 (SSRI Co., Ltd). The data to be compared were first tested for normal distribution by F-test. For comparisons between correlated data, the paired Student t-test used for normally distributed data. Wilcoxon test used for nonnormally distributed data. For comparisons between uncorrelated data, the unpaired Student t-test used for non-normally distributed data. Mann-Whitney test used for non-normally distributed data.

\section{Result}

\section{a) Result of Demiglace sauce hamburger LST test}

Table 1 shows the results of viscosity measurement performed by adding the thickener $\mathrm{A}$ in Demiglace sauce hamburger. As a result of measuring the viscosity of commercial care food without treatment, it found to be the stage 3 (Extremely thick). The result of viscosity measurement after the mixer treatment was also the stage 3 (Extremely thick). However, it found that there is a statistical advantage after 5 minutes rather than 30 seconds, and the viscosity loosens and spreads. However, when the thickener A was added (1g or $2 \mathrm{~g}$ or $3 \mathrm{~g}$ ), the LST value did not change stably even after 5 minutes as compared with after 30 seconds. The viscosity was within Stage 3.

Table 2 shows the results of viscosity measurement performed by adding the thickener $\mathrm{B}$ in Demiglace sauce hamburger. When the thickener Badded (1 $\mathrm{g}$ or $2 \mathrm{~g}$ or $3 \mathrm{~g}$ ), the LST value did not change stably even after 5 minutes as compared with after 30 seconds. The viscosity was within Stage 3.

\begin{tabular}{|c|c|c|c|c|c|c|c|c|c|c|}
\hline & \multicolumn{2}{|c|}{ No processing } & \multicolumn{2}{|c|}{ After mixing } & \multicolumn{2}{|c|}{ Add $1 \mathrm{~g}$ thickener } & \multicolumn{2}{|c|}{ Add $2 \mathrm{~g}$ thickener } & \multicolumn{2}{|c|}{ Add $3 \mathrm{~g}$ thickener } \\
\hline & After $30 \mathrm{se}$ & After $5 \mathrm{~min}$. & After $30 \mathrm{sec}$. & After $5 \mathrm{~min}$. & After $30 \mathrm{sec}$. & After $5 \mathrm{~min}$. & After $30 \mathrm{sec}$ & After $5 \mathrm{~min}$. & After $30 \mathrm{sec}$. & After $5 \mathrm{~min}$ \\
\hline Average value & 21.4 & 23.9 & 27.6 & 30.1 & 20.6 & 21.0 & 19.9 & 20.6 & 19.3 & 20.4 \\
\hline SD & 4.7 & 5.6 & 1.5 & 2.0 & 6.5 & 5.0 & 5.6 & 6.5 & 6.6 & 6.2 \\
\hline $\mathrm{F}$ test & \multicolumn{2}{|c|}{$\mathrm{P}=0.223$} & \multicolumn{2}{|c|}{$\mathrm{P}=0.147$} & \multicolumn{2}{|c|}{$\mathrm{P}=0.139$} & \multicolumn{2}{|c|}{$\mathrm{P}=1.000$} & \multicolumn{2}{|c|}{$P=1.000$} \\
\hline $\begin{array}{l}\text { Paired Student-t } \\
\text { Wilcoxon }\end{array}$ & \multicolumn{2}{|c|}{$\mathrm{P}=0.0001 * *$} & \multicolumn{2}{|c|}{$\mathrm{P}=0.0001 * *$} & \multicolumn{2}{|c|}{$\mathrm{P}=-.793$} & \multicolumn{2}{|c|}{$\mathrm{P}=0.764$} & \multicolumn{2}{|c|}{$\mathrm{P}=0.639$} \\
\hline
\end{tabular}


Table 2. Universal Design Food : UDF(Easy to bite) Demiglace sauce hamburger (Thickener B)

\begin{tabular}{|c|c|c|c|c|c|c|c|c|c|c|}
\hline & \multicolumn{2}{|c|}{ No processing } & \multicolumn{2}{|c|}{ After mixing } & \multicolumn{2}{|c|}{ Add $1 \mathrm{~g}$ thickener } & \multicolumn{2}{|c|}{ Add $2 g$ thickener } & \multicolumn{2}{|c|}{ Add $3 g$ thickener } \\
\hline & After $30 \mathrm{sec}$. & After $5 \mathrm{~min}$. & After $30 \mathrm{sec}$. & After $5 \mathrm{~min}$. & After $30 \mathrm{sec}$ & After $5 \mathrm{~min}$. & After $30 \mathrm{sec}$ & After $5 \mathrm{~min}$. & After $30 \mathrm{sec}$ & After $5 \mathrm{~min}$ \\
\hline Average value & 21.4 & 23.9 & 27.6 & 30.2 & 21.4 & 21.2 & 20.1 & 20.4 & 18.9 & 19.5 \\
\hline SD & 4.7 & 5.6 & 1.5 & 1.7 & 7.2 & 8.6 & 5.4 & 5.8 & 4.8 & 4.9 \\
\hline $\bar{F}$ test & \multicolumn{2}{|c|}{$\mathrm{P}=0.233$} & \multicolumn{2}{|c|}{$\mathrm{P}=0.321$} & \multicolumn{2}{|c|}{$\mathrm{P}=0.234$} & \multicolumn{2}{|c|}{$\mathrm{P}=0.235$} & \multicolumn{2}{|c|}{$\mathrm{P}=0.459$} \\
\hline $\begin{array}{l}\text { Paired Student-t } \\
\text { Wilcoxon }\end{array}$ & \multicolumn{2}{|c|}{$\mathrm{P}=0.0001 * *$} & \multicolumn{2}{|c|}{$\mathrm{P}=0.0001 * *$} & \multicolumn{2}{|c|}{$\mathrm{P}=0.863$} & \multicolumn{2}{|c|}{$P=0.105$} & \multicolumn{2}{|c|}{$P=0 . .58$} \\
\hline
\end{tabular}

$* \mathrm{P}<0.05, * * \mathrm{P}<0.01$

b) Result of Boiled Fried Tofu as Kyoto style LST test

Table 3 shows the results of viscosity measurement performed by adding the thickener $\mathrm{A}$ in Boiled Fried Tofu as Kyoto style. As a result of measuring the viscosity as it was on the market without treatment, it was Stage 3 after 30 seconds and Stage 2 after 5 minutes. The viscosity after the mixer treatment was in stage 2 after 30 seconds and in stage 1 after 5 minutes. When $1 \mathrm{~g}$ of thickener A added, the viscosity was Stage 3 after 30 seconds and Stage 2 after 5 minutes. The viscosity when the thickener $\mathrm{A}$ added in $2 \mathrm{~g}$ was in Stage 3 after 30 seconds and 5 minutes. When
$3 \mathrm{~g}$ of thickener A added, the viscosity was Stage 3 after 30 seconds and Stage 2 after 5 minutes.

Table 4 shows the results of viscosity measurement performed by adding the thickener Bin Boiled Fried Tofu as Kyoto style. When $1 \mathrm{~g}$ of thickener B added, the viscosity was Stage 3 after 30 seconds and Stage 2 after 5 minutes. The viscosity when the thickener $\mathrm{B}$ added in $\mathbf{2 g}$ was in Stage 3 after 30 seconds and 5 minutes. The viscosity when the thickener $\mathrm{B}$ added in $3 \mathrm{~g}$ was in Stage 3 after 30 seconds and 5 minutes.

Table 3. Universal Design Food: UDF(Easy to bite) Boiled Fried Tofu as Kyoto style (Thickener A)

\begin{tabular}{|c|c|c|c|c|c|c|c|c|c|c|}
\hline & \multicolumn{2}{|c|}{ No processing } & \multicolumn{2}{|c|}{ After mixing } & \multicolumn{2}{|c|}{ Add $1 \mathrm{~g}$ thickener } & \multicolumn{2}{|c|}{ Add $2 \mathrm{~g}$ thickener } & \multicolumn{2}{|c|}{ Add $3 \mathrm{~g}$ thickener } \\
\hline & After $30 \mathrm{sec}$ & After $5 \mathrm{~min}$. & After $30 \mathrm{sec}$. & After $5 \mathrm{~min}$. & After $30 \mathrm{sec}$. & After $5 \mathrm{~min}$. & After $30 \mathrm{sec}$. & After $5 \mathrm{~min}$. & After $30 \mathrm{sec}$. & After $5 \mathrm{~min}$. \\
\hline Average value & 29.7 & 32.2 & 35.7 & 39.5 & 31.2 & 33.9 & 20.5 & 22.2 & 21.9 & 33.2 \\
\hline$S D$ & 5.5 & 5.6 & 1.7 & 1.9 & 1.8 & 3.9 & 6.6 & 8.3 & 3.6 & 1.6 \\
\hline $\mathrm{F}$ test & \multicolumn{2}{|c|}{$\mathrm{P}=0.470$} & \multicolumn{2}{|c|}{$\mathrm{P}=0.375$} & \multicolumn{2}{|c|}{$\mathrm{P}=0.001 * *$} & \multicolumn{2}{|c|}{$\mathrm{P}=0.370$} & \multicolumn{2}{|c|}{$\mathrm{P}=0.001 * *$} \\
\hline Paired Student- $t$ & \multirow{2}{*}{\multicolumn{2}{|c|}{$\mathrm{P}=0.0001 * *$}} & \multicolumn{2}{|c|}{$\mathrm{P}=0.0001 * *$} & & & \multicolumn{2}{|c|}{$\mathrm{P}=0.234$} & \multirow{2}{*}{\multicolumn{2}{|c|}{$\mathrm{P}=0.0001 * *$}} \\
\hline Wilcoxon & & & & & $\mathrm{P}=0.0$ & $001 * *$ & & & & \\
\hline
\end{tabular}

$* \mathrm{P}<0.05, * * \mathrm{P}<0.01$

Table 4. Universal Design Food : UDF(Easy to bite) Boiled Fried Tofu as Kyoto style (Thickener B)

\begin{tabular}{|c|c|c|c|c|c|c|c|c|c|c|}
\hline & \multicolumn{2}{|c|}{ No processing } & \multicolumn{2}{|c|}{ After mixing } & \multicolumn{2}{|c|}{ Add 1g thickener } & \multicolumn{2}{|c|}{ Add $2 \mathrm{~g}$ thickener } & \multicolumn{2}{|c|}{ Add $3 \mathrm{~g}$ thickener } \\
\hline & After 30 sec. & After $5 \mathrm{~min}$. & After $30 \mathrm{sec}$. & After $5 \mathrm{~min}$. & After $30 \mathrm{sec}$ & After 5 min. & After $30 \mathrm{sec}$ & After 5 min. & After 30 & After $5 \mathrm{~min}$ \\
\hline Average value & 29.7 & 32.2 & 35.7 & 39.5 & 29.1 & 32.1 & 22.8 & 25.1 & 20.5 & 22.2 \\
\hline SD & 5.5 & 5.6 & 1.7 & 1.9 & 3.2 & 4.2 & 3.3 & 4.6 & 6.6 & 8.3 \\
\hline F test & \multicolumn{2}{|c|}{$P=0.470$} & \multicolumn{2}{|c|}{$P=0.375$} & \multicolumn{2}{|c|}{$\mathrm{P}=0.138$} & \multicolumn{2}{|c|}{$\mathrm{P}=0.077$} & \multicolumn{2}{|c|}{$\mathrm{P}=0.162$} \\
\hline $\begin{array}{l}\text { Paired Student-t } \\
\text { Wilcoxon }\end{array}$ & \multicolumn{2}{|c|}{$\mathrm{P}=0.0001 * *$} & \multicolumn{2}{|c|}{$\mathrm{P}=0.0001 * *$} & \multicolumn{2}{|c|}{$\mathrm{P}=0.058$} & \multicolumn{2}{|c|}{$\mathrm{P}=0.003 * *$} & \multicolumn{2}{|c|}{$\mathrm{P}=0 . .025 *$} \\
\hline
\end{tabular}

c) Result of White Meat fish dumpling with Egg Sauce LST test

Table 5 shows the results of viscosity measurement performed by adding the thickener $A$ in White meatfish dumpling with Egg Sauce. As a result of measuring the viscosity as it was on the market without treatment, it was Stage 3 after 30 seconds and Stage 1 after 5 minutes. The viscosity after the mixer treatment was stage 1 after 30 seconds and in stage 1 after 5 minutes. When $1 \mathrm{~g}$ of thickener $\mathrm{A}$ added, the viscosity was Stage 3 after 30 seconds and Stage 2 after 5 minutes. The viscosity when the thickener $\mathrm{A}$ added in $2 \mathrm{~g}$ was in Stage 3 after 30 seconds and 5 minutes. The viscosity when the thickener $\mathrm{A}$ added in $3 \mathrm{~g}$ was in Stage 3 after 30 seconds and 5 minutes.

Table 6 shows the results of viscosity measurement performed by adding the thickener Bin White meat fish dumpling with Egg Sauce. When the thickener B added ( $1 \mathrm{~g}$ or $2 \mathrm{~g}$ or $3 \mathrm{~g}$ ), the LST value did not change stably even after 5 minutes as compared with after 30 seconds. The viscosity was within Stage 3.

Table 5. Universal Design Food: UDF(Easy to bite) White fish dumpling with Egg Sauce (Thickener A)

\begin{tabular}{|c|c|c|c|c|c|c|c|c|c|c|}
\hline & \multicolumn{2}{|c|}{ No processing } & \multicolumn{2}{|c|}{ After mixing } & \multicolumn{2}{|c|}{ Add $1 \mathrm{~g}$ thickener } & \multicolumn{2}{|c|}{ Add $2 \mathrm{~g}$ thickener } & \multicolumn{2}{|c|}{ Add $3 \mathrm{~g}$ thickener } \\
\hline & After $30 \mathrm{sec}$ & After $5 \mathrm{~min}$. & After $30 \mathrm{sec}$. & After $5 \mathrm{~min}$. & After $30 \mathrm{sec}$. & After $5 \mathrm{~min}$. & After $30 \mathrm{sec}$. & After $5 \mathrm{~min}$. & After $30 \mathrm{sec}$. & After $5 \mathrm{~min}$ \\
\hline Average value & 31.6 & 37.1 & 39.8 & 43.5 & 30.4 & 32.7 & 21.3 & 22.1 & 20.8 & 21.7 \\
\hline SD & 9.9 & 5.7 & 1.9 & 2.0 & 2.6 & 1.7 & 8.0 & 8.8 & 6.9 & 7.0 \\
\hline $\begin{array}{l}\text { test } \\
\text { Paired Student-t }\end{array}$ & \multicolumn{2}{|c|}{$\mathrm{P}=0.012 *$} & \multirow{2}{*}{\multicolumn{2}{|c|}{$\begin{array}{c}\mathrm{P}=0.356 \\
\mathrm{P}=0.0001 * *\end{array}$}} & \multicolumn{2}{|c|}{$\mathrm{P}=0.041 * *$} & \multicolumn{2}{|c|}{$\mathrm{P}=0.201$} & \multicolumn{2}{|c|}{$\mathrm{P}=0.493$} \\
\hline $\begin{array}{l}\text { Paired Student- } \mathrm{t} \\
\text { Wilcoxon }\end{array}$ & \multicolumn{2}{|c|}{$\mathrm{P}=0.0001 * *$} & & & \multicolumn{2}{|c|}{$\mathrm{P}=0.0001 * *$} & $\mathrm{P}=0$. & $006 * x$ & & \\
\hline
\end{tabular}

$* \mathrm{P}<0.05, * * \mathrm{P}<0.01$

Table 6. Universal Design Food: UDF(Easy to bite) White fish dumpling with Egg Sauce (Thickener B)

\begin{tabular}{|c|c|c|c|c|c|c|c|c|c|c|}
\hline & \multicolumn{2}{|c|}{ No processing } & \multicolumn{2}{|c|}{ After mixing } & \multicolumn{2}{|c|}{ Add $1 \mathrm{~g}$ thickener } & \multicolumn{2}{|c|}{ Add $2 \mathrm{~g}$ thickener } & \multicolumn{2}{|c|}{ Add $3 \mathrm{~g}$ thickener } \\
\hline & After 30 sec. & After $5 \mathrm{~min}$. & After $30 \mathrm{sec}$. & After $5 \mathrm{~min}$. & After $30 \mathrm{sec}$. & After $5 \mathrm{~min}$. & After $30 \mathrm{sec}$ & After $5 \mathrm{~min}$. & After $30 \mathrm{sec}$. & After $5 \mathrm{~min}$. \\
\hline Average value & 31.6 & 37.1 & 39.8 & 43.5 & 28.4 & 30.4 & 23.1 & 24.5 & 21.3 & 22.1 \\
\hline$S D$ & 9.9 & 5.7 & 1.9 & 2.0 & 2.2 & 2.8 & 6.2 & 6.3 & 8.0 & 8.8 \\
\hline $\mathrm{F}$ test & \multicolumn{2}{|c|}{$\mathrm{P}=0.012 *$} & \multicolumn{2}{|c|}{$\mathrm{P}=0.356$} & \multicolumn{2}{|c|}{$\mathrm{P}=0.145$} & \multicolumn{2}{|c|}{$\mathrm{P}=0.478$} & \multicolumn{2}{|c|}{$\mathrm{P}=0.344$} \\
\hline Paired Student- $t$ & & & $\mathrm{P}=0$ & $001 * *$ & $\mathrm{P}=0.0$ & $0001 * *$ & $\mathrm{P}=0$. & $0001 * *$ & $\mathrm{P}=0$ & $.015 *$ \\
\hline Wilcoxon & \multicolumn{2}{|c|}{$\mathrm{P}=0.0001 * *$} & & & & & & & & \\
\hline
\end{tabular}

$* \mathrm{P}<0.05, * * \mathrm{P}<0.01$ 


\section{d) Results of comparison of two thickeners}

The result of comparing the stability of the two types of thickeners shown in Table 7, 8, and 9. In the case of the demiglace sauce hamburger, the stability was good when both the thickener $\mathrm{A}$ and the thickener $\mathrm{B}$ added, and all were in stage 3 (to see Table 7). In the case of Boiled Fried Tofu as Kyoto style, when $1 \mathrm{~g}$ of thickener added, both thickeners $\mathrm{A}$ and $\mathrm{B}$ became Stage 3 after 30 seconds and Stage 2 after 5 minutes. Thickener B was statistically significantly more stable than $\mathrm{A}$. When a thickener is added $2 \mathrm{~g}$, the thickener $\mathrm{A}$ was Stage 3 after 30 seconds, and Stage 2 after 5 minutes. But thickener B was in Stage 3 after 30 seconds and 5 minutes. Thickener $B$ was statistically significantly more stable than $A$, again. When a thickener added $3 \mathrm{~g}$, both thickeners $\mathrm{A}$ and $\mathrm{B}$ became Stage 3 after 30 seconds and Stage 2 after 5 minutes (to see Table 8). In the case of White meatfish dumpling with Egg Sauce, when a thickener is added 1g, the thickener A was Stage 3 after 30 seconds, and Stage 2 after 5 minutes. But thickener B was in Stage 3 after 30 seconds and 5 minutes. Thickener B was statistically significantly more stable than $\mathrm{A}$. when a thickener added $2 \mathrm{~g}$ or $3 \mathrm{~g}$, both thickeners $\mathrm{A}$ and $\mathrm{B}$ became Stage 3 after 30 seconds and Stage 2 after 5 minutes (to see Table 9).

\begin{tabular}{|c|c|c|c|c|c|c|c|c|c|c|c|c|}
\hline & Add $1 \mathrm{~g}$ thick & er, After 30 se & & ner, After $5 \mathrm{~min}$ & & ener, After 30 se & Add $2 \mathrm{~g}$ thic & r, After $5 \mathrm{~min}$ & Add $3 \mathrm{~g}$ thich & Anter so sec & Add $3 \mathrm{~g}$ thicl & ener, After $5 \mathrm{mi}$ \\
\hline & Thickener A & Thickener B & Thickener A & Thickener B & Thickener A & Thickener B & Thickener A & Thickener B & Thickener A & Thickener B & Thickener A & Thickener B \\
\hline Average value & 20.6 & 21.4 & 21.0 & 21.2 & 19.9 & 20.1 & 20.6 & 20.4 & 19.3 & 18.9 & 20.4 & 19.5 \\
\hline & \multirow{2}{*}{\multicolumn{2}{|c|}{$\begin{array}{l}P=0.343 \\
P=0.753\end{array}$}} & \multirow{2}{*}{\multicolumn{2}{|c|}{$\begin{array}{cr}5.0 & 8.6 \\
& P=0.015 *\end{array}$}} & \multirow{2}{*}{\multicolumn{2}{|c|}{$\begin{array}{l}P=0.438 \\
P=0.894\end{array}$}} & \multirow{2}{*}{\multicolumn{2}{|c|}{$\mathrm{P}=0.295$}} & \multirow{2}{*}{\multicolumn{2}{|c|}{$\mathrm{P}=0.085$}} & \multirow{2}{*}{\multicolumn{2}{|c|}{$\begin{aligned} 4.9 \\
P=0.155\end{aligned}$}} \\
\hline $\begin{array}{l}\text { Unparied Student-t } \\
\text { Mann-Whitney }\end{array}$ & & & & & & & & & & & & \\
\hline
\end{tabular}

Table 8. Comparison of viscosities with two thickeners (A and B) in Boiled Fried Tofu as Kyoto stylo

\begin{tabular}{|c|c|c|c|c|c|c|c|c|c|c|c|c|}
\hline - & Aad $\lg$ inice & er. After 30 se & & & & & & & & & & iener, After $5 \mathrm{mi}$ \\
\hline & Thickener A & Thickener B & Thickener A & Thickener B & Thickener A & Thickener B & Thickener A & Thickener B & Thickener A & Thickener B & Thickener A & Thickener B \\
\hline Average value & 31.2 & 29.1 & 33.9 & 32.1 & 26.0 & 22.8 & 33.2 & 25.1 & 21.9 & 20.5 & 24.8 & 22.2 \\
\hline SD & 1.8 & 3.2 & \multirow{3}{*}{\multicolumn{2}{|c|}{$\begin{array}{r}4.2 \\
\mathrm{P}=0.021 *\end{array}$}} & 4.6 & 3.3 & \multirow{2}{*}{\multicolumn{2}{|c|}{$\begin{array}{ll}1.6 & 4.6 \\
& P=0.037 * *\end{array}$}} & \multirow{3}{*}{\multicolumn{2}{|c|}{$\begin{array}{ll}3.6 \\
\mathrm{P}=0.008 * *\end{array}$}} & \multirow{3}{*}{\multicolumn{2}{|c|}{$\mathrm{P}=0.017 *$}} \\
\hline $\begin{array}{l}\text { F test } \\
\text { Unparied Student-t }\end{array}$ & \multirow{2}{*}{\multicolumn{2}{|c|}{$\begin{array}{l}\mathrm{P}=0.227 \\
\mathrm{P}=0.018 *\end{array}$}} & & & & $\begin{array}{l}P=0.098 \\
P=0.621\end{array}$ & & & & & & \\
\hline Mann-Whitney & & & & & & & & $001 * *$ & & & & \\
\hline
\end{tabular}
*P<0.05,**P<001

Table 9. Comparison of viscosities with two thickeners (A and B) in White fish dumpling with Egg Sauce

\begin{tabular}{|c|c|c|c|c|c|c|c|c|c|c|c|}
\hline & Add $1 \mathrm{~g}$ thick & er, After $30 \mathrm{sec}$. & Add $1 \mathrm{~g}$ thick & ner, After $5 \mathrm{~min}$. & Add $2 \mathrm{~g}$ thick & kener, After $30 \mathrm{sec}$. & Add $2 \mathrm{~g}$ thi & er, After $5 \mathrm{~min}$. & Add $3 \mathrm{~g}$ thick & r. After $30 \mathrm{sec}$ & Add $3 \mathrm{~g}$ thickener, After $5 \mathrm{~min}$. \\
\hline & Thickener A & Thickener B & Thickener A & Thickener B & Thickener A & A Thickener B & Thickener A & Thickener B & Thickener A & Thickener B & Thickener A Thickener B \\
\hline $\begin{array}{l}\text { Average value } \\
\text { SD }\end{array}$ & $\begin{array}{c}30.4 \\
2.6 \\
\end{array}$ & $\begin{array}{c}28.4 \\
2.2 \\
\end{array}$ & $\begin{array}{r}32.7 \\
1.7 \\
\end{array}$ & $\begin{array}{c}30.4 \\
2.8 \\
\end{array}$ & $\begin{array}{c}24.0 \\
4.6 \\
\end{array}$ & $\begin{array}{c}23.1 \\
6.2 \\
\end{array}$ & $\begin{array}{c}25.8 \\
5.6 \\
\end{array}$ & $\begin{array}{c}24.5 \\
6.3 \\
\end{array}$ & $\begin{array}{c}20.8 \\
6.9 \\
\end{array}$ & $\begin{array}{c}21.3 \\
8.0 \\
\end{array}$ & $\begin{array}{cc}21.7 & 22.1 \\
7.0 & 8.8 \\
\end{array}$ \\
\hline $\begin{array}{l}\text { F test } \\
\text { Unparied Student- } \mathrm{t}\end{array}$ & \multicolumn{2}{|c|}{$\begin{array}{l}\mathrm{P}=0.227 \\
\mathrm{P}=0.018 *\end{array}$} & \multicolumn{2}{|c|}{$\mathrm{P}=0.021 *$} & \multicolumn{2}{|r|}{$\begin{array}{l}\mathrm{P}=0.098 \\
\mathrm{P}=0.621\end{array}$} & \multicolumn{2}{|c|}{$\begin{array}{l}P=0.303 \\
P=0.530\end{array}$} & \multicolumn{2}{|c|}{$\begin{array}{l}\mathrm{P}=0.274 \\
\mathrm{P}=0.842\end{array}$} & $\begin{array}{l}P=0.163 \\
P=-0.876\end{array}$ \\
\hline
\end{tabular}

* $\mathrm{P}<0.05, * * \mathrm{P}<0.01$

\section{Discussion}

This time, the viscosity was measured using a line spread test to prepare an adjusted care food that can be provided at home using a commercially available thickener and using commercially available nursing food that can purchased at a pharmacy. The viscosity measured by combining two types of commercially available thickeners and three types of available thickeners and three types of commercially available nursing foods. The two thickeners have almost the same price and content. The contained materials differ between water-soluble dietary fiber (thickener A) and thickening polysaccharides (thickener B). Over $100 \mathrm{~g}$ of commercially available nursing food, Demiglace sauce hamburger had the highest amount of carbohydrates, Boiled Fried Tofu as Kyoto style had the highest amount of lipids, and White meat fish dumpling with Egg Sauce had the highest amount of water (less energy). When the number of carbohydrates was large, the viscosity became high by applying it to a mixer. Still, since the stable content collapses over time, it is possible to enhance the safety as a nursing food by adding a thickener to stabilize the viscosity. If the number of lipids and water is large, the viscosity will decrease with time unless a thickener added, so it is necessary to add a thickener. In the combination of the thickener and the nursing food on the market this time, if $1 \mathrm{~g}$ of the thickener added, the thickener B could stabilize the viscosity more effectively than the thickener A. Also, it is important to provide a diet high in protein to prevent sarcopenia ${ }^{2,3)}$ and flail ${ }^{4-10)}$ in nutrition. When considering the swallowing function, the viscosity of the meal in providing a safe diet is one of the important items ${ }^{11)}$. Further studies on the combination of food and thickener that are compatible with each other and the addition amount of the thickener should continued. We think it is good to continue research on nutritional supplemental drink ${ }^{12,)}$ and many other drinks ${ }^{13)}$ for senior citizens and patients.

\section{Conclusions}

Viscosity measured in different combinations of two commercially available thickeners and three commercially available care foods results. The viscosity stabilized by adding a thickener. When the amount of thickener added to food was small $(1 \mathrm{~g}$ per $100 \mathrm{~g}$ this time), thickeners containing a large number of polysaccharides made the viscosity more stable for foods containing a lot of water and lipids. However, when the added amount of thickener was large, almost the same viscosity was obtained with both the thickener 
rich in water-soluble dietary fiber and the thickener rich in polysaccharide thickener. In the future, it will be necessary to increase the number of samples and clarify the differences due to the combinations.

\section{ACKNOWLEDGEMENT}

This research was conducted by research and education expenses of Nagoya Women's University, Nagoya City, Japan.

\section{References Références Referencias}

1. Claire de Saint-Aubert, Graham Sworn and Jun Kayashita. Conparison of 2 tests used for the classification of food thickeners in the management of dysphagia. Gums and stabilisers for the food industry 17: 2014.

2. SilvaNeto LS, Karnikowiski MG, Tavares AB, Lima RM (2012) Association between sarcopenia, sarcopenic obesity, muscle strength and quality of life variables in elderly women. Rev. Bras Fisioter. 16: 360-367.

3. Go SW, Cha YH, Lee JA, Park HS (2013) Association between Sarccopenia, Bone Density, and Health-Related Quality of life in Korean Men. Korean J Fam Med. 34: 281-288.

4. Rizzoli R1, Reginster JY, Arnal JF, Bautmans I, Beaudart C, et al. (2013) Quality of life in sarcopenianad frailty. Calcif Tissue Int 93: 101-120.

5. Fried LP, Ferrucci L, Darer J, Williamson JD, Anderson $G$ (2004) untangling the concepts of disability, frailty, and comorbidity: implications for improved targeting and care. JGerontolABiolSciMedSci. 59: 255-263.

6. Ferrucci L1, Guralnik JM, Studenski S, Fried LP, Cutler GB Jr.et al (2004) designing randomized, controlled trials aimed at preventing or delaying functional decline and disability in frail, older persons: a consensus report .J am GeriatrSoc. 52: 625-634.

7. Bandeen-Roche K, Xue QL, Ferrucci L, Walston J, Guralnik JM, et al. (2006) Phenotype of frailty: characterization in the women's health and aging studies. J Gerontol A Biol Sci Med Sci. 61: 262-266.

8. Fried LP, Tangen CM, Walston J (2001) Cardiovascular Health Study Collaborative Research Group. Frailty in older adults: Evidence for a phenotype evidence for aphenotype. J Gerontol A BiolSci Med Sci. 56: 146-156.

9. Ensrud KE1, Ewing SK, Taylor BC, Fink HA, Cawthon PM, et al. (2008) Comparison of 2 frailty indexes for prediction of falls, disability, fractures, and death in older women. Arch InternMed. 168: 382-389.

10. Malafarina V1, Uriz-Otano F, Iniesta R, Gil-Guerrero $L$ (2013) Effectiveness of nutritional supplementation on muscle mass in treatment of sarcopenia in old age: a systematic review. J Am Med Dir Assoc 14: 10-17.

11. Leder SB, Judson BL, Sliwinski E, Madson L (2013) Promoting safe swallowing when puree is swallowed without aspiration but thin liquid is aspirated: nectar is enough. Dysphagia 28: 58-62.

12. Shoko Kondo, Megumi Oohashi, Naomi Katayama. (2019) Research on the combination of commercially available thickeners and nutritional supplemental drink -aiming at the care food that can be done in the general family-. Advances in Nutrition and Food science ISSN:2641-6816 (1) 1-9

13. Murray J1, Miller M, Doeltgen S, Scholten I (2014) Intake of thickened liquids by hospitalized adults with dysphagia after stroke. International Journal of Speech-Language Pathology 16: 486-494. 